\title{
Investigation and optimization of main materials consumption when mining iron ores at deep levels of the Underground Mine Group of the PJSC "ArcelorMittal Kryvyi Rih"
}

\author{
Mykola Stupnik ${ }^{1}$, Vsevolod Kalinichenko ${ }^{1 *}$, Olena Kalinichenko ${ }^{1}$, and Sofiia Yakovlieva \\ ${ }^{1}$ Kryvyi Rih National University, Department of Underground Mining of Mineral Deposit, \\ 11 Matusevycha St., 50027 Kryvyi Rih, Ukraine \\ ${ }^{2}$ Kryvyi Rih National University, student, Mining and Metallurgical Faculty, 11 Matusevycha St., \\ 50027 Kryvyi Rih, Ukraine
}

\begin{abstract}
The work considers conditions of deep levels of the Underground Mine Group for underground ore mining (as underground mines) of the Mining Department of the PJSC "ArcelorMittal Kryvyi Rih" (the PJSC "ArcelorMittal Kryvyi Rih"). The research aims to improve indicators of mined ore mass extraction when mining rich iron ores through studying and optimizing consumption of explosives, enhancing mining technology to provide fulfilment of the underground iron ore mining program. During the research, there are analyzed mining geological and technical conditions of the deposit mining as well as current technologies of iron ore mining at the Underground Mine Group of the PJSC "ArcelorMittal Kryvyi Rih". The work analyzes the achieved indices and consumption of explosives for drilling and blasting at the Underground Mine Group. The mining geological and technical conditions of the deposit mining as well as current technologies of mining, parameters of preparatory operations, the nomenclature and qualitative characteristics of many types of explosives are determined to have changed. This complicates planning consumption of explosives and making their estimates for work sites. However, this is a reason for selecting highly efficient technology and machinery in deteriorating mining and geological conditions of operating at over $1200 \mathrm{~m}$ depths. The work determines dependencies of a stress value on a mining depth and physical properties of rocks, as well as parameters of drilling and blasting operations considering the stress-strain state of the massif under high rock pressure at deep levels of the Mining Group of the PJSC “ArcelorMittal Kryvyi Rih".
\end{abstract}

\section{Introduction}

Rich iron ores (with the useful component content $58-65 \%$ in the massif) of the Underground Mine Group (as underground mines) of the Mining Department of the PJSC "ArcelorMittal Kryvyi Rih" (the PJSC "ArcelorMittal Kryvyi Rih") are mined applying

\footnotetext{
*Corresponding author: kalinichenko@,knu.edu.ua
} 
underground methods at the depths of over $1100 \mathrm{~m}$ [1 - 3]. Deepening of mining operations causes deterioration of mining-geological conditions of the iron ore deposit. Decrease of the deposit thickness and iron content in ores is one of the major deterioration indicators. Iron content decrease results in loss of iron ore consumers as current leading iron ore producers offer ores with iron content of not less than $62 \%$ [4-6].

Deterioration of mining-geological conditions caused by increased depths of mining operations leads to greater expenses on mining useful minerals [7 - 9, 13, 26, 27], increased costs of opening new levels [10 - 12], stricter requirements to applied underground mining systems [12-16] and improvement of main and auxiliary underground mining operations $[24,29,31-37]$ that impact efficiency and safety of the applied technologies.

The first step is improvement of ore breaking in stopes $[6,10,20]$. The basic requirement is consideration of the stress-strain state (SSS) of the massif $[2,8,11,12]$. Deepening of mining operations results in increased rock pressure [26, 28, 30]. Fulfilment of these requirements leads to additional costs for efficient drilling and blasting operations (DBO) [23, 28].

When drawing and transporting ore, it is necessary to consider the most efficient flowsheets of extracting ore from the massif which are used or may be used in underground operations $[1,5,13]$. Deepening requires additional expenses to maintain safe conditions of draw workings as well as for transporting ore to the shaft and winding $[3,7]$.

Increased depths of mining require greater attention to controlling the state of the massif as disturbed stability of preparatory and development workings and stopes need additional expenses for maintaining their safe condition $[4,8,19]$.

Costs for application of various concentrating methods in underground or on-surface conditions rise as well [38-42]. Some authors suggest enhancing the mined ore concentrating processes through their automation [43-47, $49-52]$. For instance, at Kiruna mine, ore is sorted underground [51-53].

The technology like that enables obtaining the final product of the appropriate quality of the useful component without concentration, clean ore extraction reaching $90-92 \%[54,55]$. Application of similar technologies at Kryvbas will lead to $2-5$-fold increase of operating costs.

Thus, investigation and optimization of main materials consumption when mining iron ores at deep levels of the Underground Mine Group (as underground mines) of the Mining Department of the PJSC "ArcelorMittal Kryvyi Rih" (the PJSC “ArcelorMittal Kryvyi Rih") are proved to be necessary.

\section{Methods}

To achieve the set objective, the authors apply the complex method of solving the following tasks:

- Analysis of mining geological and technical conditions of mining the deposit as well as the state of mining operations at deep levels of the Underground Mine Group (as underground mines) of the Mining Department of the PJSC “ArcelorMittal Kryvyi Rih";

- Analysis of the technology of mining iron ores applied at the Underground Mine Group of the PJSC "ArcelorMittal Kryvyi Rih";

- Basic statements on investigation and optimization of main materials consumption for drilling and blasting operations when mining iron ores at deep levels of the Underground Mine Group;

- Investigation and optimization of main materials consumption for drilling;

- Research and optimization of main materials consumption for blasting;

- Calculation of DBO parameters considering the SSS of the massif at deep levels of at the Underground Mine Group of the PJSC “ArcelorMittal Kryvyi Rih”. 


\section{Results and discussion}

The minefield of the deposit is located in the southern part of Saksahanska band which is the eastern Kryvorizka syncline limb.

The deposit contains six schist and six ferruginous levels.

The fifth horizon is an economic one and occurs directly on the rocks of the $5^{\text {th }}$ schist level excluding the anticlinal part where the $5^{\text {th }}$ ferruginous level rests on the $4^{\text {th }}$ ferruginous and schist level rocks due to several complicated tectonic shifts.

This level is the richest in ore and its thickness is $45-120 \mathrm{~m}$. The lithographic composition of the level is characterized by dominance of martite hornfels and jaspilites over hydrohematite-martite hornfels and jaspilites occurring in the form of small benches in the hanging and footwalls of the thickness and above iron-mica-martite hornfels and jaspilites.

The largest deposits of martite and hydrohematite-martite ores are assigned to the $5^{\text {th }}$ ferruginous level.

Fig. 1 presents a sedimentary column near the $55^{\text {th }}$ survey axis within the mining allotment of the Underground Mine Group of the PJSC “ArcelorMittal Kryvyi Rih".

At present, level $1045 \mathrm{~m}$ is the main production one of the Underground Mine Group of the PJSC “ArcelorMittal Kryvyi Rih", level $1135 \mathrm{~m}$ is in the process of building.

The ore body at the main levels is opened by haulage crosscuts. Preparation of a haulage level is fulfilled by the ort-ring pattern where field haulage drifts in the footwall and access crosscuts from the western drift are driven.

An interval between levels is $90 \mathrm{~m}$ and a level consists of three sublevels. Deposit opening at intermediate levels is performed by crosscuts from auxiliary sub-verticals of shafts to fringedrifts and then by orts driven from these drifts.

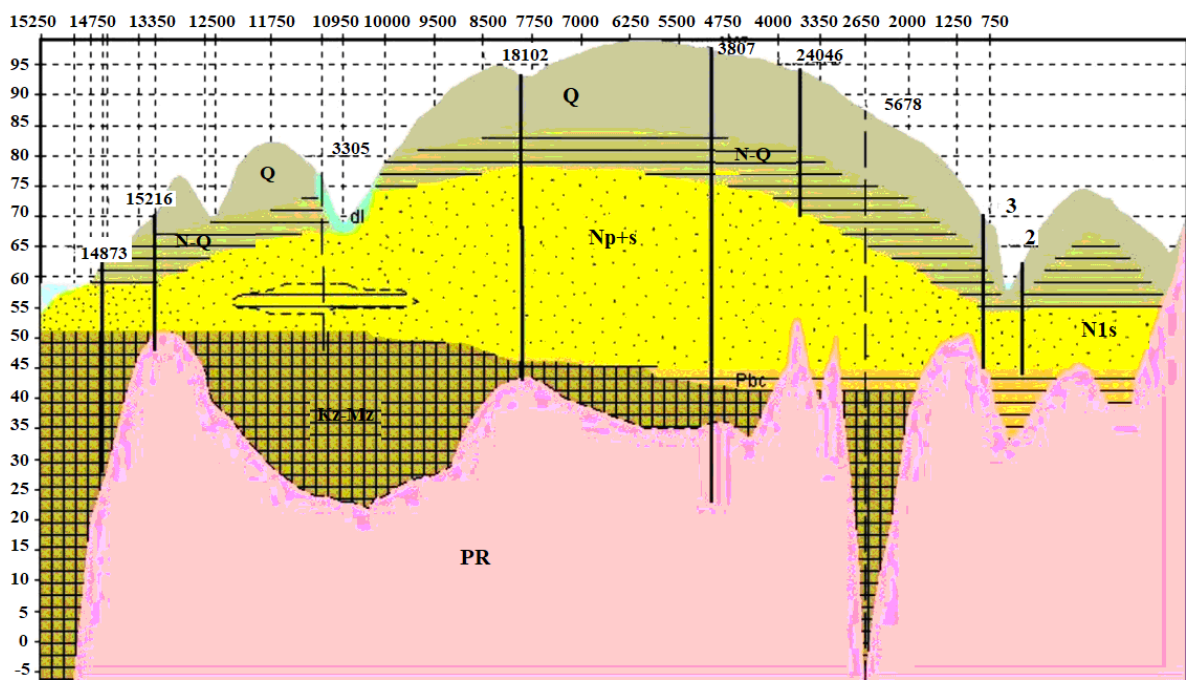

Fig. 1. Geological profile of sedimentary rocks from Karachuny water storage reservoir to the Southern open pit of the Underground Mine Group of the PJSC "ArcelorMittal Kryvyi Rih" (near the $55^{\text {th }}$ survey axis of the mining allotment).

At the Underground Mine Group, level block preparation of the ore body is applied. For this, the ore body within the level is divided on strike into $100 \mathrm{~m}$ long blocks as wide as the horizontal thickness of the ore body. The block is divided vertically into three sublevels of $30 \mathrm{~m}$ in height each. A sublevel consists of extraction panels mined onto two scraping orts 
with the following transportation of the ore along the storage drift to the orepass raise where the ore is passed to the main haulage level for loading into electromotive cars.

Due to low hardness of ore and country rock, a relatively low value of mined iron ores at the Underground Mine Group, the sublevel caving system is only used for mining. In addition, the system of drilling the ore massif with a bunch of deep raising holes from drilling cutouts of the level onto the vertical slot (compensation area) has been applied for a long time.

Figs. 2 and 3 present the mining layout on the combined level of ore drilling, drawing and transporting and vertical projections by slots (vertical compensation rooms) and drilling cutouts respectively.
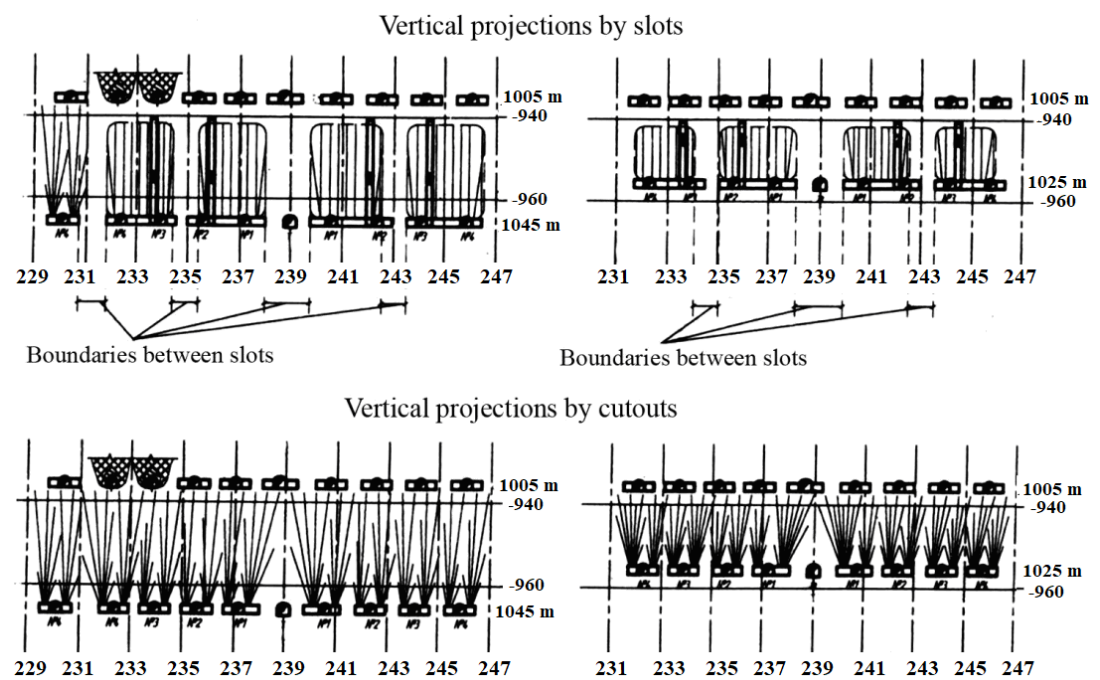

Fig. 2. Vertical projections by slots and cutouts.

In blocks, caved ore is only transported by scrapers $30 \mathrm{LS}-2 \mathrm{~S}$ in scraping orts to the storage drifts and then winches 55LS-2S take the ore to the orepass. The applied technology is characterized by the following technical and economic features:

- The required specific amount of preparatory-development workings $-3.5-5.5$, $\mathrm{m} /$ thou $\mathrm{t}$;

- Labor productivity of: a worker at driving - $0.6 \mathrm{~m} / \mathrm{manshift}$; a deep-drilling machine operator - 350 - $390 \mathrm{t} /$ manshift; an ore transportation worker $-120-125 \mathrm{t} / \mathrm{manshift}$;

- Average monthly productivity of a face -20.0 thou t;

- Ore output from $1 \mathrm{~m}$ of a hole: when forming a slot $-9.5-10.0, \mathrm{t} / \mathrm{m}$; when bulkcaving - $11.5-12.0, \mathrm{t} / \mathrm{m}$;

- Ore losses $-17-19 \%$, ore dilution $-16-18 \%$;

- Specific consumption of main materials: explosives for primary ore breaking $0.5-0.6 \mathrm{~kg} / \mathrm{t}$; explosives for secondary fragmentation $-0.05 \mathrm{~kg} / \mathrm{t}$; steel timbering $0.9-1.0 \mathrm{~kg} / \mathrm{t}$; timber $-1.5-2 \mathrm{~m}^{3} / 1000 \mathrm{t}$; power $-1.5-2.0 \mathrm{kWh} / \mathrm{t}$.

Main advantages of applying the technology consist in its constructive simplicity, low metreage of development workings and high safety of operations due to combination of drilling and transportation on a single level.

Disadvantages include some decrease of stability of haulage workings on sublevels caused by increased massif disturbance of the block foundation (especially at cutouttransportation working junction), and a low degree of mechanization (average $50-60 \%$ ) resulted from application of obsolete equipment and almost complete absence of self- 
propelled machinery. As a result, labor productivity of separate processes and the entire mining system is rather low.

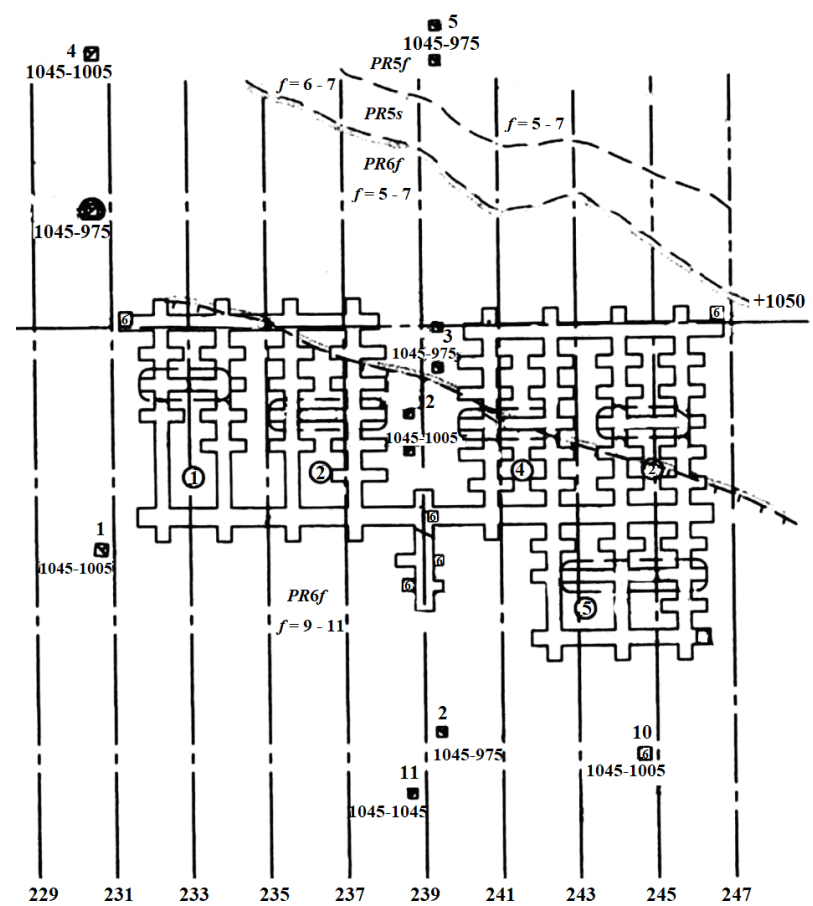

Fig. 3. Working layout of the combined level.

To optimize material consumption for mining iron ores at deep levels of the Underground Mine Group of the PJSC "ArcelorMittal Kryvyi Rih", the authors have developed an Enterprise Standard (ES). The document contains consumption standards for main materials for mining operations at the Underground Mine Group for underground ore mining (as underground mines) of the Mining Department of the PJSC "ArcelorMittal Kryvyi Rih".

Standardizing materials consumption for mining iron ores at deep levels of the Underground Mine Group includes solving the following tasks: analysis of production conditions of materials consumption and data from leading national and foreign mining enterprises; materials consumption rate setting based on scientifically substantiated standards; implementation of materials consumption rates; control of materials consumption standards in production, planning, material consumption accounting and procurement of production; implementation of technical and organizational arrangements to provide more rational and efficient use of materials; regular revision of materials consumption standards to decrease specific material consumption through implementation of innovative technologies and best practices, enhancement of production processes, etc.

The document is based on regulatory and engineering documents, technical literature and production data of the Underground Mine Group of the Mining Department of the PJSC “ArcelorMittal Kryvyi Rih” and other mining enterprises of Kryvbas.

The document offers more accurate dependencies and correction factors for perforator efficiency depending on: compressed air pressure (Table 1); the borehole diameter (Table 2); the borehole depth (Table 3). 
Table 1. Factors of correction of drilling equipment efficiency change depending on compressed air pressure.

\begin{tabular}{|l|c|c|c|c|c|c|}
\hline Compressed air pressure, $\mathrm{MPa}$ & 0.45 & 0.5 & 0.55 & 0.60 & 0.65 & 0.7 \\
\hline Factor & 0.65 & 0.80 & 0.90 & 1.0 & 1.10 & 1.20 \\
\hline
\end{tabular}

Table 2. Factors of correction of perforator efficiency change depending on the borehole diameter.

\begin{tabular}{|c|c|c|c|c|c|c|c|}
\hline Borehole diameter, $\mathrm{m}$ & 0.032 & 0.035 & 0.040 & 0.043 & 0.045 & 0.052 & 0.065 \\
\hline Factor & 1.50 & 1.25 & 1.10 & 1.00 & 0.90 & 0.80 & 0.83 \\
\hline
\end{tabular}

Table 3. Factors of correction of perforator efficiency change depending on the borehole depth.

\begin{tabular}{|c|c|c|c|c|c|c|c|}
\hline Borehole depth, $\mathrm{m}$ & 1.5 & 2.0 & 2.5 & 3.0 & 3.5 & 4.0 & 4.5 \\
\hline Factor & 1.0 & 0.97 & 0.95 & 0.93 & 0.91 & 0.90 & 0.89 \\
\hline
\end{tabular}

There are improved regularities of specific consumption of explosives in drifting faces depending on the number of exposures. Thus, specific consumption of explosives in drifting faces with two and three exposure planes is determined with the correction factors 0.85 and 0.65 respectively.

When breaking ore onto the "compressed" environment, specific consumption of explosives is increased by the value of the compression factor $F c$. The factor values (depending of the value of the ore layer shift when breaking $\Delta B, \mathrm{~m}$ ) are given in Table 4 .

Table 4. Dependency of the compression factor $F c$ on the value of the ore layer shift when breaking $\Delta B$.

\begin{tabular}{|l|c|c|c|c|c|}
\hline Value of ore layer shift when breaking $\triangle B, \mathrm{~m}$ & 1.0 & 1.5 & 2.0 & 2.5 & 3.0 \\
\hline Compression factor $F_{c}$ & 1.05 & 1.25 & 1.5 & 1.75 & 2.0 \\
\hline
\end{tabular}

Parameters of drilling and blasting operations (DBO) at stoping are calculated considering the stress-strain state of the massif.

Use of the explosion energy is ensured by the greatest degree of the massif resistance to explosive attacks along both the line of least resistance (LLR) and the hole. Excessive increase of the LLR value and decreased spacing of holes result in greater probabilities for the massif separating along the hole than before breaking. This causes shorter blasting effects on rocks and, consequently, additional decrease of breaking intensity. Excessive spacing of holes with corresponding decrease of the LLR value may lead to incomplete massif fragmentation along the hole and a wavy separation surface.

The research shows that the coefficient of column charge interaction which is a relation of optimal LLR values at companion and single blasting varies from $1.0-1.4$ if charge spacing decreases. The dependence of the coefficient of column charge interaction on the distance between charges at companion and single blasting is approximated by the expression:

$$
K_{c c i}=\sqrt{\frac{4 C_{0}^{4} d^{4} \rho^{2}+b^{4}}{2 C_{0}^{4} d^{4} \rho^{2}+b^{4}}},
$$

where $K_{c c i}$ is the coefficient of column charge interaction; $C_{0}$ is the blastability index of the environment; $d$ is the charge diameter, $\mathrm{m} ; \rho$ is the factor of explosive distribution in the massif, unit fractions; $b$ is the explosive power factor (for ammonite No. $6 \mathrm{GV} b=1$, for granulated explosives $b=0.71-1.6 \mathrm{~d}$ ).

Test blasting shows that increase of charge spacing enhances quality of massif breaking. Critical hole spacing equals the single column charge effects radius at the unlimited plane of the exposure: 


$$
b_{\max }=\sqrt{W_{s}^{2}+C_{0}^{2} d^{2} \rho},
$$

where $W_{s}$ is the LLR of a single hole, $\mathrm{m}$.

At a greater distance between charges, the separation surface becomes uneven along the hole.

If $b=b_{\max }$ and $W_{s}=C_{0} d \sqrt{\rho}$, the optimal value of the charge interaction factor is as follows: $K_{\text {cciopt }}=1.15$. With this in view, the LLR length at companion column charge firing may be calculated:

- with the limited exposure plane

$$
W_{\text {cci.opt }}=1.15 W_{s},
$$

- with the unlimited exposure plane

$$
W_{\text {cci.opt }}=1.15 C_{0} d \sqrt{\rho} .
$$

Then, the optimal value of the burden-to-spacing ratio at the optimal LLR value may be calculated from the expression:

$$
m_{\text {opt }}=\frac{b_{\max }}{W_{\text {cci.opt }}}=\frac{1.41 C_{0} d \sqrt{\rho}}{1.15 C_{0} d \sqrt{\rho}}=1.22,
$$

which is practically proved by drilling and blasting operations at Kryvbas underground mines.

However, to decrease substandard yield, closer borehole spacing is sometimes applied as compared with maximum parameters. In this case, the burden-to-spacing ratio will not remain fixed as the optimal distance between holes is not proportionally dependent on the LLR value change.

On replacing $W_{s}=W_{c c i} / K_{c c i}$ in the expression and taking the optimal value $K_{c c i}=1.15$, the authors obtain the formula for determining the optimal distance between column charges at their simultaneous firing for any LLR values:

$$
b_{o p t}=\sqrt{0.756 W_{c c i}^{2}+C_{0}^{2} d^{2} \rho} .
$$

Also, this technique enables considering effects of the stress-strain state of the massif on DBO parameters that may considerably impact ore breaking quality. As for massif breaking, the value of stresses and their distribution are conditioned mainly by the mining depth, sizes and orientation of compensation rooms or exposures onto which ore is broken.

When designing $\mathrm{DBO}$, the stress-strain state of the massif is considered through the coefficient of energy intensity of breaking $K \sigma$. The coefficient equals the ratio of specific consumption of explosives which is determined considering the impact of mining depth and stope sizes $q_{\sigma}$ to specific consumption of explosives determined considering hardness of ore to break $q$ :

The numerical value of the coefficient is calculated by the expressions:

- when breaking ore onto the horizontal compensation area:

$$
k_{\sigma}^{h}=1.5+\frac{1}{q} \cdot\left(0.4 \cdot \exp \left(-\frac{B}{W}\right)-\frac{S_{h} \cdot \sqrt{H}}{f \cdot 10^{4}}\right),
$$

- when breaking ore onto vertical slots or exposures:

$$
k_{\sigma}^{v}=1.5+\frac{1}{q} \cdot\left(0.4 \cdot \exp \left(-\frac{B}{W}\right)-\frac{S_{v} \cdot \sqrt{\frac{H \cdot \mu}{1-\mu}}}{f \cdot 10^{4}}\right),
$$


where $B$ is the width of the stoping area, $\mathrm{m} ; S_{h}, S_{v}$ are the area of the horizontal or vertical stope respectively, $\mathrm{m}^{2} ; H$ is the mining depth, $\mathrm{m} ; \mu$ is the Poisson ratio.

Considering the stress-strain state of the massif, blastability indices of specific consumption of explosives for breaking, the LLR value is determined by the formulas:

$$
C_{\sigma}=\frac{C_{0}}{\sqrt[3]{k_{\sigma}}} ; q_{\sigma}=q \cdot k_{\sigma} ; W_{\sigma}=\frac{W}{\sqrt[3]{k_{\sigma}}} .
$$

It is advisable to use TNT-free explosives as TNT is dangerous due to its explosibility, and its toxicity causes up to thirty human diseases. Wider application of non-electric blasting supplies is also expedient.

\section{Conclusions}

The authors have: analyzed mining geological and technical conditions of the deposit development as well as the current state of mining operations at deep levels of the Underground Mine Group for underground ore mining (as underground mines) of the Mining Department of the PJSC “ArcelorMittal Kryvyi Rih"; revealed major disadvantages of the iron ore mining technology applied at the Underground Mine Group of the PJSC "ArcelorMittal Kryvyi Rih"; designed main directions of investigation and optimization of drilling and blasting costs when mining iron ore at deep levels of the Underground Mine Group; investigated and optimized material consumption for drilling; specified dependencies and suggested correction factors for drilling the rock massif with drilling equipment; determined dependencies of the stress value on the mining depth and physical properties of rocks; determined parameters of DBO considering the stress-strain state of the massif; optimized explosives consumption for mining iron ores under high rock pressure at deep levels of Underground Mine Group of the PJSC “ArcelorMittal Kryvyi Rih”.

The authors would like to thank the management of the Underground Mine Group for underground ore mining (as underground mines) of the Mining Department of the PJSC "ArcelorMittal Kryvyi Rih" for their help with the work "Development of the reference book "Rates of consuming basic material resources for mining operations at the Underground Mine Group for underground ore mining (as underground mines) of the Mining Department of the PJSC "ArcelorMittal Kryvyi Rih" under Contract № 2111 of 21 October, 2019.

\section{References}

1. Stupnik, M., Kolosov, V., Pysmennyi, S. \& Kovbyk, K. (2019). Selective mining of complex stuctured ore deposits by open stope systems. E3S Web of Conferences, (123), 01007. https://doi.org/10.1051/e3sconf/201912301007

2. Stupnik, M.I., Kalinichenko, V.O., Kalinichenko, O.V., Muzika, I.O., Fed'ko, M.B., \& Pismennyi, S.V. (2015). The research of strain-stress state of magnetite quartzite deposit massif in the condition of mine "Gigant-Gliboka" of central iron ore enrichment works (CGOK). Metallurgical and Mining Industry, (7), 377-383.

3. Stupnik, N., Kalinichenko, V., Pismennij, S. \& Kalinichenko, E. (2015). Features of underlying levels opening at "ArsellorMittal Kryvyic Rih" underground mine. New Developments in Mining Engineering 2015: Theoretical and Practical Solutions of Mineral Resources Mining, 39-44. https://doi.org/10.1201/b19901-8

4. Stupnik, N., \& Kalinichenko, V. (2012). Parameters of shear zone and methods of their conditions control at underground mining of steep-dipping iron ore deposits in Kryvyi Rig basin. Geomechanical Processes During Underground Mining - Proceedings of the School of Underground Mining, 15-17. https://doi.org/10.1201/b13157-4 
5. Kalinichenko, O., Fedko, M., Kushnerov, I., \& Hryshchenko, M. (2019). Muck drawing by inclined two-dimensional flow. E3S Web of Conferences, (123), 01015. https://doi.org/10.1051/e3sconf/201912301015.

6. Stupnik, N.I., Kalinichenko, V.A., Fedko, M.B., \& Mirchenko, Ye.G. (2013). Prospects of application of TNT-free explosives in ore deposites developed by uderground mining. Naukovyi Visnyk Natsionalnoho Hirnychoho Universytetu, (1), 44-48.

7. Stupnik, M., \& Kalinichenko, V. (2013). Magnetite quartzite mining is the future of Kryvyi Rig iron ore basin. Annual Scientific-Technical Collection - Mining of Mineral Deposits 2013, 49-52. https://doi.org/10.1201/b16354-10

8. Stupnik, N.I., Kalinichenko, V.A., Fedko, M.B., \& Mirchenko, Ye.G. (2013). Influence of rock massif stress-strain state on uranium ore breaking technology. Naukovyi Visnyk Natsionalnoho Hirnychoho Universytetu, (2), 11-16.

9. Stupnik, M., Kalinichenko, V., Fedko, M., Kalinichenko, O., Pukhalskyi, V., \& Kryvokhin, B. (2019). Investigation of the dust formation process when hoisting the uranium ores with a bucket. Mining of Mineral Deposits, 13(3), 96-103. https://doi.org/10.33271/mining13.03.096

10. Stupnik, M.I. , Kalinichenko, O.V. , Kalinichenko, V.O. (2012). Economic evaluation of risks of possible geomechanical violations of original ground in the fields of mines of Kryvyi Rih basin. Naukovyi Visnyk Natsionalnoho Hirnychoho Universytetu, (6), 126-130.

11. Stupnik, M., Kalinichenko, O., Kalinichenko, V., Pysmennyi, S. \& Morhun, O. (2018). Choice and substantiation of stable crown shapes in deep-level iron ore mining. Mining of Mineral Deposits, 12(4), 56-62. https://doi.org/10.15407/mining12.04.056

12. Kalinichenko, V.O., Dolgikh, O.V., \& Dolgikh, L.V. (2019). Digital survey in studying open pit wall deformations. E3S Web of Conferences, (123), 01047. https://doi.org/10.1051/e3sconf 201912301047.

13. Pysmenniy, S., Shvager, N., Shepel, O. \& Kovbyk, K., \& Dolgikh O. (2020). Development of resource-saving technology when mining ore bodies by blocks under rock pressure. E3S Web of Conferences, (166), 02006. https://doi.org/10.1051/e3sconf/202016602006

14. Pysmennyi, S., Brovko, D., Shwager,N., Kasatkina, I., Paraniuk, D., \& Serdiuk, O. (2018). Development of complexstructure ore deposits by means of chamber systems under conditions of the Kryvyi Rih iron ore field. Eastern-European Journal of Enterprise Technologies, 5(1(95)), 33-45. https://doi.org/10.15587/1729-4061.2018.142483

15. Dolgikh, O., \& Dolgikh, L. (2020). The study of the collapse zone by remote methods. E3S Web of Conferences, (166), 03002. https://doi.org/10.1051/e3sconf/202016603002

16. Andreev, B.M., Brovko, D.V., \& Khvorost, V.V. (2015). Determination of reliability and justification of object parameters on the surface of mines taking into account change-over to the lighter enclosing structures. Metallurgical and Mining Industry, (12), 378-382.

17. Tron, V., Tsokurenko, O., Paraniuk, D., \& Haponenko, I. (2019). Formation of the adaptive fuzzy model of the rock geological structure for exploratory drilling. E3S Web of Conferences, (123), 01037. https://doi.org/10.1051/e3sconf/201912301037

18. Serhiienko, V. (2019). Defectoscope for monitoring of a concrete timbering of underground $\begin{array}{lllll}\text { constructions. } \quad E 3 S \quad W e b & \text { of } & \text { Conferences, } & \text { (109), }\end{array}$ https://doi.org/10.1051/e3sconf/201910900084

19. Tarasyutin, V.M. (2015). Geotechnology features of high quality martite ore from deep mines of Kryvyi Rih basin. Naukovyi Visnyk Natsionalnoho Hirnychoho Universytetu, (1), 54-60.

20. Rymarchuk, B.I., Shepel, O.L., \& Khudyk, M.V. (2017). Expediency of application of the vertical concentrated charges to decrease losses of ore on a lying wall of deposits. Naukovyi Visnyk Natsionalnoho Hirnychoho Universytetu, (3), 32-37.

21. Khomenko, O., \& Rudakov, D. (2010). The first Ukrainian corporative university. New Techniques and Technologies in Mining - Proceedings of the School of Underground Mining, 203-206. https://doi.org/10.1201/b11329-34

22. Kononenko, M., Khomenko, O., Savchenko, M., \& Kovalenko, I. (2019). Method for calculation of drilling-and-blasting operations parameters for emulsion explosives. Mining of Mineral 
Deposits, 13(3), 22-30. https://doi.org/10.33271/mining13.03.022

23. Khomenko, O., Rudakov, D., \& Kononenko, M. (2011). Automation of drill and blast design. Technical and Geoinformational Systems in Mining: School of Undergroumd Mining 2011, 271275. https://doi.org/10.1201/b11586-45

24. Kononenko, M., \& Khomenko, O. (2010). Technology of support of workings near to extraction chambers. New Techniques and Technologies in Mining - Proceedings of the School of Underground Mining, 193-197. https://doi.org/10.1201/b11329-32

25. Khomenko, O., Kononenko, M., \& Myronova, I. (2017). Ecological and technological aspects of iron-ore underground mining. Mining of Mineral Deposits, 11(2), 59-67. https://doi.org/10.15407/mining11.02.059

26. Khomenko, O.Ye. (2012). Implementation of energy method in study of zonal disintegration of rocks. Naukovyi Visnyk Natsionalnoho Hirnychoho Universytetu, (4), 44-54.

27. Khomenko, O., Kononenko, M., Kovalenko, I., \& Astafiev, D. (2018). Self-regulating roofbolting with the rock pressure energy use. E3S Web of Conferences, (60), 00009. https://doi.org/10.1051/e3sconf/20186000009

28. Khomenko, O., Kononenko, M., \& Myronova, I. (2013). Blasting works technology to decrease an emission of harmful matters into the mine atmosphere. Annual Scientific-Technical Colletion Mining of Mineral Deposit, 231-235. https://doi.org/10.1201/b16354-43

29. Kuz'menko, O., Petlyovanyy, M., \& Stupnik, M. (2013). The influence of fine particles of binding materials on the strength properties of hardening backfill. Annual Scientific-Technical Colletion - Mining of Mineral Deposits, 45-48. https://doi.org/10.1201/b16354-10

30. Khomenko, O., Kononenko, M., \& Bilegsaikhan, J. (2018). Classification of Theories about Rock $\begin{array}{llll}\text { Pressure. Solid } & \text { State }\end{array}$ https://doi.org/10.4028/www.scientific.net/ssp.277.157

31. Vladyko, O., Kononenko, M., \& Khomenko, O. (2012). Imitating modeling stability of mine workings. Geomechanical Processes During Underground Mining - Proceedings of the School of Underground Mining, 147-150. https://doi.org/10.1201/b13157-26

32. Khalymendyk, I., \& Baryshnikov, A. (2018). The mechanism of roadway deformation in conditions of laminated rocks. Journal of Sustainable Mining, 17(2), 41-47. https://doi.org/10.1016/j.jsm.2018.03.004

33. Babets, D.V., Sdvyzhkova, O.O., Larionov, M.H., Tereshchuk, R.M. (2017). Otsinka stiikosti masyvu hirskykh porid, shcho bazuietsia na ymovirnisnomu pidkhodi ta reitynhovykh klasyfikatsiiakh. Naukovyi visnyk $N H U,(2), 58-64$.

34. Malanchuk, Z.R., Moshynskyi, V.S., Korniienko, V.Y., Malanchuk, Y.Z., \& Lozynskyi, V.H. (2019). Obgruntuvannia parametriv rozmyvu y peretikannia pulpy tseolit-smektytovoho tufu u vydobuvnii kameri. Naukovyi visnyk $N H U,(6), 11-18$.

35. Petlovanyi, M., Kuzmenko, O., Lozynskyi, V., Popovych, V., Sai, K., \& Saik, P. (2019). Review of man-made mineral formations accumulation and prospects of their developing in mining industrial regions in Ukraine. Mining of Mineral Deposits, 13(1), 24-38. https://doi.org/10.33271/mining13.01.024

36. Dychkovskyi, R., Vladyko, O., Maltsev, D., Cabana, E.C. (2018). Some aspects of the compatibility of mineral mining technologies. Rudarsko-Geološko-Naftni Zbornik, 33(4), 73-82. https://doi.org/10.17794/rgn.2018.4.7

37. Dreus, A.Yu., Sudakov, A.K., Kozhevnikov, A.A., Vakhalin, Yu.N. (2016). Study on thermal strength reduction of rock formation in the diamond core drilling process using pulse flushing mode. Naukovyi Visnyk Natsionalnoho Hirnychoho Universytetu, (3), 5-10.

38. Morkun, V., Morkun, N., \& Pikilnyak, A. (2014). The adaptive control for intensity of ultrasonic influence on iron ore pulp. Metallurgical and Mining Industry, (6), 8-11.

39. Golik, V., Komashchenko, V., \& Morkun, V. (2015). Feasibility of using the mill tailings for preparation of self-hardening mixtures. Metallurgical and Mining Industry, 7(3), 38-41.

40. Morkun, V., Morkun, N., \& Pikilnyak, A. (2014). Ultrasonic facilities for the ground materials characteristics control. Metallurgical and Mining Industry, (2), 31-35. 
http://www.metaljournal.com.ua/assets/Journal/a6.pdf

41. Morkun, V., Morkun, N., \& Pikilnyak, A. (2015). Adaptive control system of ore beneficiation process based on Kaczmarz projection algorithm. Metallurgical and Mining Industry, (2), 35-38.

42. Morkun, V., \& Tron, V. (2014) Automation of iron ore raw materials beneficiation with the operational recognition of its varieties in process streams. Metallurgical and Mining Industry, (6), 4-7.

43. Golik, V., Mitsik, M., Morkun, V., Morkun, N., \& Tron, V. (2019). Transportation of concentration and leaching tailings in underground mining of metal deposits. Mining of Mineral Deposits, 13(2), 111-120. https://doi.org/10.33271/mining13.02.111

44. Morkun, V., Morkun, N., \& Tron, V. (2015). Distributed control of ore beneficiation interrelated processes under parametric uncertainty. Metallurgical and Mining Industry, 7(8), 18-21.

45. Morkun, V., \& Morkun, N. (2018). Estimation of the crushed ore particles density in the pulp flow based on the dynamic effects of high-energy ultrasound. Archives of Acoustics, 43(1), 61-67.

46. Morkun, V., Morkun, N., \& Pikilnyak, A. (2015). The study of volume ultrasonic waves propagation in the gas-containing iron ore pulp. Ultrasonics, (56), 340-343. https://doi.org/10.1016/j.ultras.2014.08.022

47. Morkun, V., Morkun, N., \& Pikilnyak, A. (2014) Ultrasonic phased array parameters determination for the gas bubble size distribution control formation in the iron ore flotation. Metallurgical and Mining Industry, (3), 28-31.

48. Morkun, V. \& Tron, V. 2014. Ecological and economic optimization of iron ore processing automated control. Metallurgical and Mining Industry, 6(5), 8-10.

49. Lutsenko, I., Fomovskaya, E., Koval, S., \& Serdiuk, O. (2017). Development of the method of quasioptimal robust control for periodic operational processes. Eastern-European Journal of Enterprise Technologies, 4(2(88)), 52-60. https://doi.org/10.15587/1729-4061.2017.10754

50. Plevako, V., Potapov,V., Kycenko, V., Lebedynecj I., \& Pedorych, I. (2016). Analytical study of the bending of isotropic plates, inhomogeneous in thickness. Eastern-European Journal of Enterprise Technologies, 4(7(82)), 10-16. https://doi.org/10.15587/1729-4061.2016.75052

51. Herbert, R., \& Nordström, A. (2017). Leachate generation and nitrogen release from small-scale rock dumps at the Kiruna iron ore mine. In International Mine Water Association Conference (pp. 140-146).

52. Behzad, Ghodrati, \& Uday, Kumar, (2005). Reliability and operating environment-based spare parts estimation approach: A case study in Kiruna Mine, Sweden. Journal of Quality in Maintenance Engineering, 11(2), 169-184. https://doi.org/10.1108/13552510510601366

53. Wimmer, M., Nordqvist, A., Righetti, E., \& Petropoulos, N. (2015). Analysis of rock fragmentation and its effect on gravity flow at the Kiruna sublevel caving mine. In 11th International Symposium on Rock Fragmentation by Blasting (pp. 775-791). Carlton VIC: The Australasian Institute of Mining and Metallurgy.

54. Carusone, O., \& Hudyma, M. (2017). Variations in apparent stress and energy index as indicators of stress and yielding around excavations. Proceedings of the First International Conference on Underground Mining Technology, 205-218. https://doi.org/10.36487/acg_rep/1710 16 carusone

55. Hudyma, M.R., Potvin, Y, Grant, D.R., Milne, D., Brummer, R.K., \& Board, M. (1994). Geomechanics of Sill Pillar Mining. Rock Mechanics Models and Measurements Challenges from Industry. In $1 s t$ North American Rock Mechanics Symposium (pp. 969-976). The University of Texas at Austin. 